\title{
Al-Madãris
}

VOL. 2, NO. 1, 2021

E-ISSN: 2745-9950

https://journal.staijamitar.ac.id/index.php/almadaris

\section{PERAN PEMERINTAH DALAM PEMBERDAYAAN EKONOMI MASYARAKAT MELALUI BAITUL MAL DI ACEH}

\author{
Riski Azhari \\ Program Magister Sosiologi, Fakultas Ilmu Sosial dan Ilmu Politik, \\ Universitas Malikussaleh \\ rikigoshu@gmail.com \\ Wais Alqarni \\ Prodi Ilmu Pemerintahan Fakultas Ilmu Sosial dan Ilmu Politik, \\ Universitas Syiah Kuala \\ waisalqarni@unsyiah.ac.id
}

\author{
Abidin Nurdin \\ Fakultas Ilmu Sosial dan Ilmu Politik, Universitas Malikussaleh \\ abidin@unimal.ac.id
}

Abstract

This study discusses the role of government in community economic empowerment through Baitul Mal in Aceh. This study aims to contribute to the government on social issues such as poverty and underdevelopment. The method used in this study is qualitative research with data collection techniques, namely the study of literature. While the theory used is structural functionalism theory. Research findings from the discussion and analysis above that the Government of Aceh through Baitul Mal has played a role in empowering the economic community in Aceh in the form of productive Zakat, Infaq and Shadaqah. The government through Baitul Mal has carried out programs (a) providing business capital to the people who have their businesses to develop their businesses, both in the agriculture, animal husbandry, industrial, and trade sectors, (b) providing assistance in working tools, in the form of motorized pedicabs, and the tools needed in the agriculture, animal husbandry, trading, and industrial sectors that

$\overline{\text { Al-Madãris, Volume 2 (1), } 2021}$ 
support their businesses, and (c) human resource development through skills training and skills to the community. This community economic empowerment program clearly contributes to social problems such as poverty, under development and access to education.

Keywords: Aceh Goverment, Baitul Mal, ZIS, and Community Economic Empowerment.

\section{A. Pendahuluan}

Pemerintah memiliki peran dan tanggungjawab yang besar dalam mengembangkan ekonomi masyarakat. Pemerintah Aceh melalui lembaga Baitul Mal telah melakukan pemberdayakan ekonomi masyarakat dalam bentuk pendistribusian zakat, Infaq dan Shadaqah. Zakat tidak hanya berfungsi sebagai ibadah yang bersifat vertikal kepada Allah, namun zakat juga berfungsi sebagai wujud ibadah yang bersifat horizontal. Zakat memiliki manfaat yang sangat penting dan strategis dilihat dari sudut pandang ajaran Islam maupun dari aspek pembangunan ekonomi masyarakat. Membayar zakat, secara sosiologis merupakan manifestasi kewajiban dari solidaritas sosial (Anwar, 2018: 42).

Baitul Mal merupakan lembaga yang dibentuk oleh pemerintah untuk menyimpan dan mengelola segala macam harta yang menjadi pendapatan Negara. Merujuk pada Qanun Aceh No. 10 Tahun 2007, bahwa Baitul Mal adalah Lembaga Daerah Non Struktural yang diberi kewenangan untuk mengelola dan mengembangkan zakat, wakaf, harta agama dengan tujuan untuk kemaslahatan umat serta menjadi wali/wali pengawas terhadap anak yatim piatu dan/atau hartanya serta pengelolaan terhadap harta warisan yang tidak ada wali berdasarkan Syariat Islam (Pasal l, Ayat 11).

Menurut Undang-Undang No. 11 Tahun 2006 tentang Pemerintah Aceh menegaskan bahwa zakat, harta wakaf dan harta agama dikelola oleh Baitul Mal Aceh dan Baitul Mal Kabupaten/Kota yang diatur dengan Qanun Aceh No. 10 Tahun 2007 tentang Baitul Mal. Pembentukan Baitul Mal di Aceh berkaitan dengan pembentukan lembaga zakat atau harta agama di daerah lain di Indonesia. Sejak tahun 1973 di Aceh telah dibentuk satu lembaga yang dinamakan Badan Penertiban Harta Agama (BPHA) dengan Surat Keputusan Gubernur No. 52 Tahun 1973 yang mengatur adanya lembaga ini, sejak dari Provinsi, Kabupaten/Kota, Kecamatan sampai BPHA Kampung (Musa, 2008: 185).

Pada tahun 2007, eksistensi Baitul Mal diperkuat dengan lahirnya Qanun Aceh No 10 Tahun 2007 tentang Baitul Mal dimana dalam pasal 3 ayat 1 menyebutkan Baitul Mal adalah lembaga daerah non struktural yang dalam melaksanakan tugasnya bersifat independen sesuai dengan ketentuan syariat dan bertanggung jawab kepada gubernur. Dengan terbentuknya Baitul Mal di Aceh, diharapkan mampu berperan aktif dalam mengumpulkan zakat dan dapat disalurkan kepada orang-orang yang berhak menerimanya, dengan harapan dapat membantu menunjang perekonomian yang lebih baik dan kehidupan yang bermartabat.

$\overline{\text { Al-Madãris, Volume 2 (1), } 2021}$ 
Sebagaimana yang dijelaskan dalam Qanun Aceh No 10 Tahun 2007 tentang Baitul Mal pasal 29 bahwa zakat didayagunakan untuk mustahik baik yang bersifat produktif maupun konsumtif berdasarkan ketentuan syari'at Islam. Hal ini dapat dipahami bahwa pengelolaan zakat seperti menyalurkan zakat kepada mustahik tidak hanya diberikan untuk di konsumsi, melainkan dapat bersifat produktif yaitu memberdayakan masyarakat.

Namun penggunaan zakat yang bersifat produktif masih minim dilaksanakan. padahal ini sangat penting untuk memberdayakan masyarakat terutama fakir miskin untuk meningkatkan perekonomian masyarakat melalui dan memutuskan rantai kemiskinan di Aceh. Jika melihat dari berbagai penelitian sebelumnya tentang Baitul Mal, misalnya penelitian Nasrullah (2015) menjelaskan bahwa peran Baitul Mal dalam mengelola zakat masih bersifat pasif dimana hanya berperan sebagai pihak penghimpun dan dan menyalurkan kepada para mustahiq, sehingga pengelolaan zakat lebih bersifat konsumtif. Padahal zakat juga bisa dikembangkan sebagai modal usaha untuk memberdayakan ekonomi masyarakat, sehingga pengelolaan zakat dapat bersifat lebih produktif.

Firdaus dan Mukhlish (2017) menjelaskan peran Baitul Mal dalam menurunkan kemiskinan melalui penyaluran zakat kepada para mustahiq secara umum masih bersifat konsumtif dan hanya dalam persentase kecil yang disalurkan bersifat produktif. Kondisi tidak banyak membantu masyarakat miskin dalam jangka panjang, karena tetap menjadi penerima zakat abadi. Padahal maksud utama dari penyaluran zakat bertujuan untuk menyejahterakan masyarakat miskin dalam segala aspeknya baik aspek ekonomi, sosial, budaya, pendidikan, kesehatan dan lainnya.

Berdasarkan latar belakang tersebut kajian ini bertujuan untuk membahas tentang peran pemerintah dalam pemberdayaan ekonomi masyarakat melalui Baitul Mal di Aceh. Kajian ini penting dilakukan untuk memberikan konstribusi terhadap peran dan tanggung jawab pemerintah mengenai masalah-masalah sosial misalnya kemiskinan dan keterbelakangan.

\section{B. Review Literatur}

\section{Teori Pemberdayaan}

Teori yang penulis gunakan dalam kajian ini adalah teori Fungsionalisme Struktural Robert K Merton. Menurut teori ini masyarakat merupakan suatu sistem sosial yang terdiri atas bagian atau elemen yang saling berkaitan dan saling menyatu dalam keseimbangan. Perubahan yang terjadi pada satu bagian akan membawa perubahan pula pada bagian yang lain. Asumsi dasarnya ialah setiap struktur dalam sistem sosial, fungsional terhadap yang lain. Sebaliknya kalau tidak fungsional maka struktur itu tidak akan ada atau akan hilang dengan sendirinya (Ritzer, 2004: 21).

Di dalam fungsionalisme struktural, istilah struktur dan fungsional tidak selalu dihubungkan, meski keduanya biasanya dihubungkan, meski keduanya biasa di hubungkan. Struktur masyarakat dapat di pelajari tanpa memperhatikan fungsinya (atau akibatnya) terhadap struktur lain. Begitu juga dapat di teliti fungsi berbagai proses sosial yang mungkin tidak mempunyai struktur (Ritzer dan

Al-Madaris, Volume 2 (1), 2021 
Goodman, 2007: 118). Merton mengutip tiga postulat yang terdapat dalam analisa fungsional yang kemudian disempurnakannya satu demi satu.

Postulat pertama adalah kesatuan fungsional masyarakat yang dapat dibatasi sebagai suatu keadaan dimana seluruh bagian dari sistem sosial bekerja sama dalam suatu tingkat keselarasan atau konsistensi internal yang memadai, tanpa menghasilkan konflik berkepanjangan yang tidak dapat diatasi atau diatur. Merton menegaskan bahwa fungsional yang sempurna dari suatu masyarakat adalah bertentangan dengan fakta. Sebagai contoh dia mengutip beberapa kebiasaan masyarakat yang dapat bersifat fungsional bagi suatu kelompok (menunjang integrasi dan kohesi suatu kelompok) akan tetapi disfungsional (mempercepat kehancuran) bagi kelompok lain (Poloma, 2010: 36).

Paradigma Merton menegaskan bahwa disfungsi (elemen disintegratif) tidak boleh diabaikan hanya karena orang begitu terpesona oleh fungsi-fungsi positif (elemen integratif). Ia juga menegaskan bahwa apa yang fungsional bagi suatu kelompok dapat tidak fungsional bagi keseluruhan. Oleh karena itu batas-batas kelompok yang dianalisa harus diperinci (Poloma, 2010: 36)

Postulat kedua, yaitu fungsionalisme universal. Fungsionalisme universal menganggap bahwa seluruh bentuk sosial dan kebudayaan yang sudah baku memiliki fungsi-fungsi positif. Sebagaimana sudah ketahui, Merton memperkenalkan konsep disfungsi maupun fungsi positif. Beberapa perilaku sosial jelas bersifat disfungsional. Merton menganjurkan agar elemen-elemen kultural seharusnya dipertimbangkan menurut kriteria keseimbangan konsekuensi-konsekuensi fungsional, yang menimbang fungsi positif relatif terhadap fungsi negatif.

Postulat ketiga adalah postulat indispensability. Ia menyatakan bahwa dalam setiap tipe peradaban, setiap kebiasaan, ide, obyek materiil, dan kepercayaan memenuhi beberapa fungsi penting, memiliki sejumlah tugas yang harus dijalankan, dan merupakan bagian penting yang tidak dapat dipisahkan dalam kegiatan sistem sebagai keseluruhan. Menurut Merton, postulat ini masih kabur. Belum jelas apakah fungsi (suatu kebutuhan sosial seperti reproduksi anggota-anggota baru) atau item (sebuah norma, seperti keluarga batih), merupakan suatu keharusan (Poloma, 2010: 37).

\section{Baitul Mal dan Pemberdayaan Ekonomi Masyarakat}

Baitul Mal merupakan salah satu institusi pengelolaan harta agama yang sudah muncul pertama kali sejak setelah turunnya wahyu yang memerintahkan Rasulullah untuk membagikan ghanimah dari perang Badr dan beriringan pula dengan turunnya ayat 1 surat Al-Anfal, meskipun secara kelembagaan baru dipraktekan pada masa Khulafa ar-Rasyidin (Zallum, 1983: 45).

Baitulmal berasal dari bahasa Arab bait yang berarti rumah, dan al-mal yang berarti harta. Secara etimologis Baitulmal berarti rumah untuk mengumpulkan atau menyimpan harta (Muhammad, 2005: 1). Sementara makna secara terminologis sebagaimana uraian Zallum (1983: 64) bahwa Baitulmal adalah suatu lembaga yang

$\overline{\text { Al-Madaris, Volume 2 (1), } 2021}$ 
mempunyai tugas khusus menangani harta, baik berupa pendapatan maupun pengeluaran negara.

Sebenarnya pengelolaan zakat di Aceh mengacu pada Undang-Undang Nomor 38 Tahun 1999, kemudian pada tahun yang sama juga keluar Undang-Undang Nomor 44 Tahun 1999 tentang Keistimewaan Aceh. Turunan dari Undang-undang yang disebut terakhir adalah keluarnya Peraturan Daerah (Perda) Tahun 2000 Tentang Pelaksanaan Syari'at Islam. Salah satu dari isi Perda tersebut adalah membentuk Badan Baitul Mal. Badan ini baru dibentuk pada tahun 2003 melalui Keputusan Gubernur Nomor 18 Tahun 2003 (yang seharusnya dibentuk dengan Qanun/Perda) dan baru mulai beroperasi pada tahun 2004. Selanjutnya setelah tercapainya MoU Helsinki antara Pemerintah dan Gerakan Aceh Merdeka (GAM) tanggal 15 Agustus 2005, maka lahirlah Undang-Undang Nomor 11 Tahun 2006 tentang Pemerintahan Aceh. Dalam Pasal 191 secara jelas disebutkan pembentukan Baitul Mal sebagai lembaga pengelola zakat, harta wakaf dan harta agama akan dibentuk dengan Qanun Aceh (Armiadi Musa, 2014: 355).

Berdirinya Baitul Mal di Aceh juga diperkuat dengan lahirnya Qanun Aceh No 10 Tahun 2007 tentang Baitul Mal menjelaskan Baitul Mal adalah Lembaga Daerah Non Struktural yang diberi kewenangan untuk mengelola dan mengembangkan zakat, wakaf, harta agama dengan tujuan untuk kemaslahatan umat serta menjadi wali/wali pengawas terhadap anak yatim piatu dan/atau hartanya serta pengelolaan terhadap harta warisan yang tidak ada wali berdasarkan Syariat Islam (Pasal l, ayat 11 ).

Qanun Aceh No 10 Tahun 2007 pasal 8 menjelaskan fungsi dan kewenangan sebagai berikut:

a. Mengurus dan mengelola zakat, wakaf, dan harta agama

b. Melakukan pengumpulan, penyaluran dan pendayagunaan zakat

c. Melakukan sosialisasi zakat, wakaf dan harta agama lainnya

d. Menjadi wali terhadap anak yang tidak mempunyai lagi wali nasab, wali pengawas terhadap wali nashab, dan wali pengampu terhadap orang dewasa yang tidak cakap melakukan perbuatan hukum

e. Menjadi pengelola terhadap harta yang tidak diketahui pemilik atau ahli warisnya berdasarkan putusan Mahkamah Syari'ah dan

f. Membuat perjanjian kerjasama dengan pihak ketiga untuk meningkatkan pemberdayaan ekonomi umat berdasarkan prinsip saling menguntungkan.

Peran pemerintah melalui Baitul Mal Aceh dalam pengelolaan zakat sebagaimana yang dijelaskan dalam Qanun Aceh No 10 Tahun 2007 tentang Baitul Mal pasal 29 bahwa zakat didayagunakan untuk mustahik baik yang bersifat produktif maupun konsumtif berdasarkan ketentuan syari'at. Mustahik zakat untuk usaha produktif harus memenuhi syarat sebagai berikut: (a) adanya suatu jenis usaha produktif yang layak, (b) bersedia menerima petugas pendamping yang berfungsi sebagai pembimbing/penyuluh; dan bersedia menyampaikan laporan usaha secara periodik setiap 6 (enam) bulan. Pengelolaan zakat bersifat produktif dimana penggunaan zakat kepada berbagai program peningkatan ekonomi masyarakat

Al-Madãris, Volume 2(1), 2021 
melalui program pemberdayaan ekonomi. Jadi dapat ditegaskan bahwa terbentuknya Baitul Mal juga tidak dapat dipisahkan dari penerapan Syariat Islam di Aceh, karena Baitul Mal secara struktur pemerintahan merupakan bagian dari dari lembaga dan dinas yang berada dibawah kendali Gubernur dan Wakilnya sebagaimana Dinas Syariat Islam, Dinas Pendidikan Dayah, Majelis Pendidikan Aceh, Majelis Adat Aceh.

Oleh karena itu, pemberdayaan ekonomi masyarakat melalui zakat yang diberikan kepada mustahiq akan berperan sebagai pendukung peningkatan ekonomi mereka apabila dikonsumsikan pada kegiatan produktif. Pendayagunaan zakat produktif sesungguhnya mempunyai konsep perencanaan dan pelaksanaan yang cermat seperti mengkaji penyebab kemiskinan, ketidakadaan modal kerja, dan kekurangan lapangan kerja, dengan adanya masalah tersebut maka perlu adanya perencanaan yang dapat mengembangkan zakat bersifat produktif tersebut. Pengembangan zakat bersifat produktif dengan cara menjadikan dana zakat sebagai modal usaha, untuk pemberdayaan ekonomi penerimanya, dan supaya fakir miskin dapat menjalankan atau membiayai kehidupannya secara konsisten. Dengan dana zakat tersebut fakir miskin akan mendapatkan penghasilan tetap, meningkatkan usaha, mengembangkan usaha serta mereka dapat menyisihkan penghasilannya untuk menabung (Anwar, 2018: 47).

Pada konteks yang lebih jauh, sebagai pemerintah melalui Baitul Mal berperan melakukan pemberdayaan ekonomi masyarakat dalam bentuk zakat produktif. Artinya tidak hanya tergantung pada zakat konsumtif, atau pembagian zakat yang habis dikomsumsi oleh penerimanya. Zakat produktif tersebut akan lebih bermanfaat secara berkelanjutan dan berkesinambungan tidak habis dikonsumsi dalam waktu singkat.

\section{Metodelogi}

Kajian ini merupakan studi kualitatif dengan menjadikan lembaga Baitul Mal sebagai studi kasus. Metodologi kualitatif merupakan prosedur penelitian yang menghasilkan data deskriptif berupa kata-kata tertulis atau lisan dari orang-orang dan perilaku yang dapat diamati dan diarahkan pada latar dan individu tersebut secara holistik (Moleong, 1997: 3). Kemudian teknik pengumpulan data menggunakan studi literatur yang merupakan teknik yang dipakai untuk mengumpulkan data dalam bentuk tulisan. Data yang dimaksud dapat berupa: jurnal, buku, laporan penelitian, aturan hukum dan berbagai sumber tulisan lainnya (Moleong, 1997: 219). Sejumlah data tersebut kemudian di analisis dengan menggunakan teori pemberdayaan masyarakat sebagaimana yang telah dijelaskan.

\section{Hasil dan Pembahasan}

Pemerintah sebagai eksekutif yang menjalankan pemerintahan telah mengeluarkan regulasi terakit dengan pengelolaan zakat yaitu Baitul Mal mulai dari provinsi sampai pada level gampong. Kelahiran Qanun No. 7 Tahun 2004 yang mengatur pengelolaan zakat merupakan respons yang bisa dianggap sebagai jawaban terhadap optimalisasi potensi zakat di Indonesia selama ini masih jauh dari yang

$\overline{\text { Al-Madãris, Volume 2 (1), } 2021}$ 
diharapkan. Keberadaan Qanun ini juga bisa merupakan respons terhadap UndangUndang No. 38 Tahun 1999 tentang Zakat yang masih memiliki kekurangan yang besar, terutama pasal-pasal yang mengatur tentang sanksi bagi penyimpangan terhadap pengelolaan zakat. Pada Undang-Undang, sanksi lebih banyak diatur pada penyimpangan bagi amil zakat sedang pada Qanun pengelolaan zakat ini sudah mencakup amil dan muzakki serta pelimpahan wewenang yang amat besar bagi pengelolaan zakat oleh Baitul Mal (Djawas, 2016: 101).

Sejalan dengan itu pemerintah melalui Undang-Undang Nomor 18 tahun 2001 zakat ditetapkan sebagai salah satu sumber PAD (pendapatan asli daerah). Di dalam ketentuan Qanun tentang zakat ini, sangat jelas ditentukan bahwa zakat hanya disalurkan kepada mustahiq sesuai dengan syari'at Islam. Hal ini menunjukkan bahwa zakat tidak bisa digunakan untuk keperluan yang tidak termasuk ke dalam salah satu dari senif yang sudah jelas disebutkan dalam AlQur'an (Djawas, 2016: 101).

Pada konteks yang lebih luas, Baitul Mal sebagai lembaga yang memiliki kewenangan mengelola zakat, infak dan shadaqah sebagai pendapatan asli daerah akan memberikan kontribusi untuk pemberdayaan masyarakat. Clutterbuck (dalam Lubis, 2016) pemberdayaan dipahami sebagai upaya mendorong dan memberikan individu kesempatan untuk mengambil tanggung jawab pribadi dalam meningkatkan cara melakukan pekerjaan dan kontribusinya guna mencapai tujuan organisasi.

Ide pemberdayaan sendiri memiliki dua kecenderungan jika dilihat dari sudut operasionalisasinya. Pertama, kecenderungan primer, merupakan kecenderungan proses yang memberikan atau mengalihkan sebagian kekuasaan, kekuatan, dan kemampuan (power) kepada masyarakat atau individu untuk lebih berdaya. Proses ini dilengkapi dengan upaya membangun aset material guna mendukung pembangunan kemandirian melalui organisasi. Kedua, kecenderungan sekunder, yaitu kecenderungan yang menekankan pada proses memberikan stimulasi, mendorong atau memotivasi individu agar mempunyai kemampuan atau keberdayaan untuk menentukan apa yang menjadi pilihan hidupnya melalui proses dialog (Sumodiningrat, 1999: 52).

Jika dilihat partisipasi sebagai salah satu komponen penting pada proses pemberdayaan, maka bisa dipahami bahwa proses pemberdayan dapat dilakukan secara individual maupun kelompok (kolektif). Namun demikian, seperti ditegaskan Freidmann, karena proses pemberdayaan merupakan proses dari wujud perubahan sosial atau status hierarki yang dicirikan dengan adanya polarisasi ekonomi, maka kemampuan individu senasib untuk saling berkumpul dalam suatu kelompok cenderung dinilai sebagai bentuk pemberdayaan yang paling efektif (Lubis, 2016).

Pemberdayaan ekonomi masyarakat menurut Kartasasmita (dalam Karim, 1999: 10) adalah upaya pengerahan sumberdaya untuk mengembangkan potensi ekonomi rakyat untuk meningkatkan produktivitas rakyat sehingga, baik sumberdaya manusia maupun sumberdaya alam disekitar kberadaan rakyat, dapat ditingkatkan produktivitasnya. Pengembangan ekonomi masyarakat adalah suatu $\overline{\text { Al-Madãris, Volume 2 (1), } 2021}$ 
usaha bersama dan terencana untuk meningkatkan kualitas kehidupan manusia dalam bidang ekonomi.

Ada beberapa model pemberdayaan ekonomi melalui zakat (Hafidhuddin dan Juwaini, 2006: 64) yaitu:

1. Karitas atau program bantuan sosial dalam bentuk hibah atau pendayagunaan zakat yang mamanfaatnya diterima lansung oleh mustahiq. Contoh: bantuan makanan, tempat tinggal, beasiswa, transportasi dan bantuan dakwah.

2. Pengembangan insan yaitu program peningkatan sumberdaya manusia seperti peningkatan kapasitas mustahiq; manajemen usaha, pelatihan wirausaha, dan lainnya

3. Pengembangan ekonomi yaitu program peningkatan penghasilan dan kemandirian usaha. Contohnya fasilitasi wirausahawan baru, bantuan modal usaha, dan lainnya.

Baitulmal di Aceh berperan dalam mengelola zakat, dan nantinya zakat tersebut disalurkan kepada fakir miskin. Penyaluran zakat ada bersifat konsumtif dan produktif. Awal mula adanya program pemberdayaan ekonomi masyarakat itu disalurkan melalui zakat produktif. Landasan syariah pada model penyaluran zakat produktif adalah tatkala Rasulullah SAW. menyerahkan dana zakat kepada Salim bin Abdillah bin Umar untuk dikembangkan dan disedekahkan kembali. Berkaitan dengan hal ini, Yusuf al-Qardhawi menyatakan bahwa dana zakat dapat dipergunakan untuk membangun pabrik atau perusahaan yang kepemilikan dan penggunaannya ditujukan untuk fakir miskin, sehingga kebutuhan hidup mereka lebih terjamin karena terdapat sumber yang pasti (Aflah dan Tajang, 2006: 13).

Salah satu penggunaan bersifat produktif yang dilakukan oleh Baitul Mal Aceh dengan merumuskan program pemberdayaan masyarakat, melalui pemberian modal usaha maupun perlengkapan alat yang mendukung pekerjaannya. Pemberdayaan ekonomi masyarakat melalui Baitul Mal Aceh dilakukan melalui program produktif untuk peningkatan ekonomi masyarakat, misalnya program ZIS Produktif yaitu program pemberikan kesempatan kepada wirausahaan kecil agar terus berkembang produktif dan mandiri. Program terbaru lainnya adalah Program Gampong Produktif dengan pemberian bantuan kepada gampong yang memiliki usaha mikro masyarakat.

Baitul Mal Aceh dengan merumuskan program ZIS Produktif berupa pemberian modal usaha dalam bentuk pinjaman lunak/qardul hasan. Program ini sudah ada semenjak tahun 2006 dan berjalan hingga 2015. Program ini sudah membina 2083 mustahik kelompok usaha kecil yang ada di Aceh seperti Banda Aceh dan Aceh Besar dengan memberikan modal usaha kepada fakir miskin yang bertani palawija, pedagang kecil, industri rumahan, peternakan dan berupa barang seperti becak motor (Baitulmal.acehprov.go.id, di akses 29 Desember 2018).

Terkait konsep pembedayaan ekonomi masyarakat diperkuat oleh pendapat Hafidhuddin dan Juwaini (2006: 64), menjelaskan beberapa model pemberdayaan ekonomi zakat produktif melalui pengembangan ekonomi yaitu program

$\overline{\text { Al-Madãris, Volume 2 (1), } 2021}$ 
peningkatan penghasilan dan kemandirian usaha. Model pemberdayaan ini sudah dijalankan oleh Baitul Aceh melalui program ZIS Produksi.

Sebagaimana yang dijelaskan Sumodiningrat (1999: 32) bahwa konsep pemberdayaan ekonomi sebagai kegiatan pemberdayaan masyarakat salah satunya mencakup peningkatan akses ke sarana dan prasarana yang mendukung langsung sosial ekonomi masyarakat lokal. Program ini sudah dilaksanakan Baitul Mal Aceh melalui pemberian bantuan peralatan kerja, baik dibidang peternakan, pertanian, perdagangan, dan industri rumahan. Berikut daftar penerima manfaat dan pemberdayaan masyarakat yang dilakukan oleh Baitul Mal dari 2013-2017.

Tabel 1. Jumlah Penerimaan Manfaat Program Zakat dan Infaq Baitul Mal Aceh Tahun 2013 s.d 2017

\begin{tabular}{clccccc}
\hline No & Program & 2013 & 2014 & 2015 & 2016 & 2017 \\
\hline 1 & Beasiswa & 1918 & 1592 & 3351 & 5125 & 2815 \\
\hline 2 & Fakir Uzur & 1067 & 1111 & 1561 & 2000 & 1813 \\
\hline 3 & Paket Ramadhan & 3550 & 3000 & 4000 & 6000 & 6000 \\
\hline 4 & Muallaf & 214 & 258 & 311 & 412 & 442 \\
\hline 5 & Alat Kerja & - & - & 607 & 363 & 48 \\
\hline 6 & Insidentil & 138 & 148 & 313 & 176 & 164 \\
\hline 7 & Reward Tahfidz & - & - & 300 & - & - \\
\hline \multirow{2}{*}{8} & Pembangunan Rumah Fakir & - & 1000 & - & - & - \\
& Miskin & 10 & & 24 & 20 & 10 \\
\hline 9 & Baitul Mal Gampong & 860 & 914 & 191 & - & - \\
\hline 10 & ZIS Produktif & 7757 & 8023 & 10658 & 14096 & 11292 \\
\hline & Total & & & & &
\end{tabular}

Sumber: Laporan Tahunan Baitul Mal, 2017.

Dari data tersebut di atas menunjukkan bahwa kehadiran pemerintah Aceh melalui Baitul Mal program pemberdayaan ekonomi masyarakat telah dilakukan misalnya, bantuan modal usaha melalui baitul mal gampong sekitar 50 juta, bantuan pembelian alat kerja 150 juta kepada 48 orang, renovasi rumah fakir dan miskin 5,6 miliyar, pemberdayaan muallaf, beasiswa anak miskin dan anak muallaf 1,6 miliyar. (Laporan Tahunan Baitul Mal, 2017: 46-50). Jadi singkatnya bahwa peran pemerintah melalui Baitul Mal dalam melakukan pemberdayaan ekonomi masyarakat telah berjalan dengan baik dan dirasakan manfaatnya terutama masyarakat miskin dan yang membutuhkan bantuan.

Selain itu, baitul mal juga melakukan program pengembangan insan sudah dilaksanakan oleh Baitul Mal Aceh melalui pelatihan skill seperti pelatihan baby sitter, computer, pelatihan untuk anak berkebutuhan khusus, dan keterampilan berkarakter (baitulmal.acehprov.go.id, di akses 29 Desember 2018). Hafidhuddin dan Juwaini (2006: 64) menerankan bahwa model lain dari pemberdayaan ekonomi melalui ekonomi produksi dilakukan dengan pengembangan insan. Pernyataan di atas juga didukung oleh pendapat Sumodiningrat (1999: 33) tentang bentuk 
pemberdayaan masyarakat dapat dilakukan melalui peningkatan akses pengembangan SDM melalui pelatihan.

Pemberdayaan ekonomi masyarakat sebagaimana yang jelaskan Freidmann dapat bersifat individu maupun kolektif. Menurut Freidmann (Lubis, 2016: 27) proses pemberdayaan merupakan proses dari wujud perubahan sosial atau status hierarki yang dicirikan dengan adanya polarisasi ekonomi, maka kemampuan individu senasib untuk saling berkumpul dalam suatu kelompok cenderung dinilai sebagai bentuk pemberdayaan yang paling efektif. Program pemberdayaan ekonomi yang dilakukan oleh Baitul Mal Aceh dengan memberikan bantuan, misalnya modal usaha dapat bersifat perorangan maupun kolektif dimana mereka sama-sama bekerja mengembangkan usahanya.

Program pemberdayaan ekonomi melalui Baitul Mal dilakukan melalui pemberian modal usaha, peralatan kerja baik berbasis individu maupun kelompok dan gampong. Selama tiga tahun terakhir yaitu 2015, 2016, 2017 dimana sudah ada 32 gampong di bina Baitul Mal Aceh menuju gampong produktif berbasis kearifan lokal. Gampong binaan Baitul Mal Aceh diarahkan untuk memiling branding one village one product sebagai sumber perberdayaan ekonomi masyarakat (Serambinews.com. 2017).

Jika dideskripsikan pendekatan teori Fungsionalisme Struktural yang dikemukakan oleh Merton dengan kajian ini dapat dipahami bahwa Baitul Mal Aceh dapat dikatakan sebagai sebuah sistem dimana lembaga ini memiliki bagian mulai dari tingkat provinsi, kabupaten, mukim hingga gampong. Setiap bagian memiliki tugas dan saling terintegrasi. Selanjutnya, memiliki regulasi hukum terkait tugas/wewenang dan tanggung jawab yang diembannya. Sebagai sebuah sistem, diharapkan lembaga ini dapat berfungsi semestinya dan dapat mewujudkan tujuan dari berdirinya lembaga ini.

Berdasarkan teori di atas, ada tiga postulat fungsionalisme struktural menurut Merton bahwa: Postulat pertama, membahas tentang kerja sama antar bagian dalam satu sistem. Pemerintah Aceh melalui Baitul Mal memainkan fungsi kerja sama salah satunya dengan gubernur sebagai penanggung jawab atas berdirinya lembaga ini. Kerja sama tersebut tidak hanya dengan pihak gubernur tetapi juga antar bagian/unit kerja di Baitul Mal ditingkat provinsi, kabupaten, mukim, dan gampong. Postulat kedua, yaitu fungsionalisme universal. Salah satu fungsi yang dibahas dalam konsep ini yaitu fungsi positif. Keterkaitan konsep ini dalam membahas fungsi lembaga Baitul Mal Aceh yaitu fungsi lembaga ini dalam memberdayakan ekonomi masyarakat dengan membuat berbagai program pemberdayaan sebagai fungsi positif. Hal ini terlihat adanya bantuan modal usaha pada tahun 2017, ada 491 penerima modal usaha dan 48 penerima bantuan alat kerja di Banda Aceh dan Aceh Besar. Ada bantuan program gampong produktif yang bersifat kolektif. Ada 10 gampong yang ada di wilayah Aceh Besar, Aceh Utara, Aceh Jaya, dan Aceh Barat yang mendapatkan bantuan modal usaha (Laporan Tahunan Baitul Mal, 2017). Pada tahun 2018, ada peningkatan penerima bantuan alat kerja, pertama ada 55 fakir miskin menerima bantuan tersebut, dan bertambah 118 fakir miskin mendapatkan bantuan serupa.

$\overline{\text { Al-Madãris, Volume 2(1), 2021 }}$ 
Postulat ketiga adalah postulat indispensability. Konsep ini membahas tentang fungsi penting. Terkait dengan fungsi Baitul Mal Aceh dalam mengelola zakat terdapat fungsi penting. Hal dianggap penting disini pada penyaluran zakat yang bersifat konsumtif dan produktif. Selama ini penyaluran zakat yang dianggap penting lebih bersifat konsumtif dengan membuat berbagai program yang kebanyakan bersifat konsumtif. Padahal pengelolaan zakat bersifat produktif juga lebih penting untuk memberdayakan ekonomi masyarakat, sehingga perlu ada perhatian khusus terkait dengan program pemberdayaan ini. Jika program ini dianggap penting dan menguatkan berbagai program pemberdayaan ekonomi dapat membantu mengurangi angka kemiskinan dan membantu meningkatkan kesejahteraan masyarakat.

\section{E. Kesimpulan}

Kesimpulan ringkas dari pembahasan dan analisis di atas bahwa peran bahwa Pemerintah Aceh melalui Baitul Mal telah berperan melakukan pemberdayaan ekonomi masyarakat di Aceh dalam bentuk Zakat Infak dan Shadaqah yang produktif. Pemerintah melalui Baitul Mal melakukan program; (a) memberikan modal usaha kepada masyarakat yang memiliki usahanya untuk mengembangkan usahanya, baik usaha sektor pertanian, peternakan, industri, maupun perdagangan, (b) memberikan bantuan alat-alat kerja, baik berupa becak motor, maupun alat yang dibutuhkan di sektor pertanian, peternakan, berdagang, dan industri yang mendukung usahanya, dan (c) pengembangan SDM melalui pelatihan skill dan keterampilan untuk masyarakat seperti pelatihan baby sitter, komputer, pelatihan untuk anak berkebutuhan khusus, dan keterampilan berkarakter. Program pemberdayaan ekonomi masyarakat ini jelas memberikan kontribusi bagi permasalahan-permasalahan sosial seperti kemiskinan, keterbelakangan dan akses terhadap pendidikan.

\section{BIBLIOGRAFI}

Aflah, Kuntarno Noor \& Mohd. Nasir Tajang. (2006). Zakat dan Peran Negara. Jakarta: FOZ.

Anwar, Ahmad Thoharul. (2018). Zakat Produktif Untuk Pemberdayaan Ekonomi Umat, Ziswaf: Jurnal Zakat dan Wakaf, Vol. 5, No. 1, Juni.

Baitul Mal Aceh. (2018). Baitulmal, Acehprov.go.id, di akses 29 Desember 2018.

Baitul Mal Sabang Salur Modal Usaha Untuk Ratusan Masyarakat Kurang mampu. (2018). Diakses 01 Januari 2019, dari serambinews.com.

Baitul Mal Serahkan Peralatan Kerja. (2018). Diakses 01 Januari 2019, dari serambinews.com.

Djawas, Mursyid, (2016). Implementasi Pengelolaan Zakat Di Aceh, Mazahib: Jurnal Pemikiran Hukum Islam, Vol. XV, No. 1, Juni.

$\overline{\text { Al-Madaris, Volume 2 (1), } 2021}$ 
Firdaus, Rayyan \& Mukhlish M. Nur. (2017). Model Pemberdayaan Ekonomi Berbasis Zakat Produktif dalam Meningkatkan Pendapatan Masyarakat di Provinsi Aceh. FEB Universitas Malikussaleh, Lhokseumawe Aceh.

Hafidhuddin, Didin \& Ahmad Juwaini. (2006). Membangun Peradaban Zakat. Jakarta: Bamuis BNI \& IMZ.

Karim, Ahmad. (1999). Sistem, Prinsip, dan Tujuan Ekonomi Islam. Bandung: Pustaka Setia.

Komitmen Baitul Mal Aceh Untuk Pemberdayaan Umat. (2017). Diakses 01 Januari 2019, dari serambinews.com

Laporan Tahunan Baitul Mal Aceh Tahun 2017.

Lexy J., Moleong. (1997). Metode Penelitian Kualitatif. Bandung: Rosda Karya.

Lubis, Fauzi Arif. (2016). Peranan BMT dalam Pemberdayaan Ekonomi Nasabah Di Kecamatan Berastagi-Kabanjahe Kabupaten Karo (Studi Kasus BMT Mitra Simalem Al-Karomah). Jurnal Human Falah: Vol 3. No. 2 Juli - Desember.

Muhammad, Ridwan. (2005). Sistem Dan Prosedur Mendirikan BMT: Panduan Kongres Nasional Lembaga Keuangan Mikro Syariah Baitul Maal wat Tamwil. Jakarta: PINBUK.

Musa, Armiadi. (2008). Zakat Produktif: Solusi Alternatif Pemberdayaan Ekonomi Umat (Potret dan Praktek Baitul Mal Aceh). Yogyakarta: Ar-Raniry Press Darussalam Banda Aceh \& AK GROUP Yogyakarta.

Musa, Armiadi. (2014). Kontribusi Pemerintah dalam Pengelolaan Zakat di Aceh (Kontestasi Penerapan Asas Lex Specialis dan Lex Generalis), Jurnal Media Syariah, Vol.XVI No. 1 Juni.

Nasrullah. (2015). Regulasi Zakat Dan Penerapan Zakat Produktif Sebagai Penunjang Pemberdayaan Masyarakat (Studi Kasus Pada Baitul Mal Kabupaten Aceh Utara). Jurnal Penelitian Sosial Keagamaan. Vol. 9, No. 1, Juni.

Poloma, Margaret M. (2010). Sosiologi Kontemporer. Jakarta: Raja Grafindo Persada.

Qanun Aceh No. 10 Tahun 2007 tentang Baitul Mal.

Sumodiningrat, Gunawan. (1999). Pemberdayaan Masyarakat dan Jaring Pengaman Sosial. Jakarta: Gramedia.

Undang-Undang No. 11 Tahun 2006 tentang Pemerintahan Aceh.

Zallum, Abdul Qadir. (1983). Amwal Fi Daulah Al-Khilafah. Beirut: Darul 'Ilmi Lil Malayin.

$\overline{\text { Al-Madãris, Volume 2 (1), } 2021}$ 